\title{
Paradigm for the development of a Lanna music curriculum in Higher Education in Northern Thailand
}

\author{
Khanithep Pitupumnak \\ Faculty of Fine Arts, Chiang Mai University \\ 239 T.Suthep, A. Muang, Chiang Mai 50202, Thailand \\ e-mail: khanithep@gmail.com
}

Published online: 10 August 2018

Cite this article (APA): Putipumnak, K (2018). Paradigm for the development of a Lanna music curriculum in High Education in Northern Thailand. Malaysian Journal of Music, 7, 38-57.

\begin{abstract}
This article reviews the status of Lanna music in higher education, offering suggestions for the development of Lanna music in Northern Thai universities. The researcher adopts a phenomenological method, utilising data from a number of interviews $(\mathrm{N}=20)$ and observations. The results suggest that Lanna music in higher education plays a significant role in shaping the cultural identity of the community. This unique style of music is often taught as a core area of study, as an extension to existing music curricula, or is being offered elsewhere as a general subject of study pursued by non-music students. In the development of Lanna music curricula, the main objective is to sustain musical traditions, musical creativity and to promote professionalism in performance. The curriculum needs to consider the readiness of the elements, especially those pertaining to culture and community, which form the foundation of knowledge. The curriculum should develop learners on the basis of their interests and potentials and promote a local program which is attentive to local contexts. Finally, the curriculum should consider the diversity of culture and needs of the community.
\end{abstract}

Keywords: institutionalisation, Lanna music, Northern Thailand, traditional music curriculum, traditional music education

\section{Introduction}

The word 'Lanna' is used to delineate a cultural space in northern Thailand, consisting of eight provinces to include Chiang Mai, Chiang Rai, Lampoon, 
Lampang, Phayao, Phrae, Nan and Mae Hong Son. The Lanna culture dates back 700 years at the very least; it is a culture which combines the ways of life of various people living together or apart within the region. Through the ages, the Lanna culture has undergone numerous transformations in accordance with economic, political and cultural factors, both at the national and international levels. Subsequently, in 1997, a state-constituted initiative was created, which was fuelled by the works of various historians, conservationists, artists and locals, in order to revive the Lanna tradition. The Lanna renaissance was carried out through different means such as preservationist work, research, activities, recontextualisation and education (Akins \& Binson, 2011; Pitupumnak, 2017; Kanteewong, n.d.). During this time, numerous groups and organisations committed to the preservation and transference of the Lanna culture were formed, including: The Center for the Promotion of Arts and Culture, the Lanna Wisdom School and various community music projects. The Thai Government saw it fit to mandate the sustainability of culture as one of four key objectives of higher education, the others being teaching, research and academic services.

Music is an aspect of the Lanna tradition which has seen developments much like other arts. Lanna music has owed its longevity and survival because it was required and necessarily to accompany many Northern Thai cultural events. Some forms of music have lost their appeal, whilst others continue to evolve, responding to changes in social conditions. In any case, the revivalist trend of late has seen many lost musical traditions restored. In the academic sphere, there has been a surge of interest in Lanna music both in Thailand and abroad. (Akins \& Binson, 2011; Dyck, 2010; Pitupumnak, 2014)

From the music education perspective, Lanna music is transmitted in two ways: the formal and informal education (Akins \& Binson, 2011). The informal education of Lanna music includes self-learning, musical training at the house of music masters, musical learning as part of communal activities and so forth. The strength of this former method of transmission is that the learners become involved at the very start of their interest. They become aware of the musical contexts in which they operate, learning about the place of music in a multidimensional society. They learn about change, adaptability, variable social demands, creativity in response to social demands and so forth. Learners of all ages and genders can participate at this level of music education (Pitupumnak, 2017). However, the informal education systems still lacks the element of professionalism, in that it does not lead to job security or to other creative avenues - all important factors in the development of Lanna music and musicians. As for transmission within the formal education, Lanna music is often inserted into existing music curricula, or even as part of extra-curricular activities. Having said this, the Bunditpatanasilpa Institute, which was established by the Ministry of Culture, has developed a curriculum of Lanna music, in effect since 2012.

Lanna music is undergoing significant changes on an aggregate level, which is a cause for major concern, as it may lead to the disappearance of this unique music style. Obviously, it is critical for Lanna music to evolve and develop in order to initiate more creativity and knowledge, and to create future career opportunities for artists. Nevertheless, there are major weaknesses in the management system. The 
succession depends on the individual, the teacher, the community leader, or the manager (Pitupumnak, 2017). The Lanna music that exists in higher education however, is not appropriately suited to develop academic knowledge, traditional music education creativity and superior performance (Pitupumnak, 2017; Thongkam, 2014). Therefore, the need for the development of transmission and specialisation of Lanna music intensifies. The development of musical skills, creative and academic work, performance forms and opportunities, as well as the adaptation of the musical profession to new global trends and challenges should thus be the central aim of the (new) Lanna music curriculum in formal education. This article presents the status of Lanna music in higher education and the paradigm for the development of a Lanna music curriculum in higher education so to reflect social conditions and $21^{\text {st }}$ century demands.

\section{Lanna Music}

Lanna music is considered as one of the most widely distributed music in the Northern Thai region. Historically, Lanna music was documented around 650 years ago based on inscriptions found at Phra Yuen Temple in the Lampoon province, built in 1370 (The inscriptions in Thailand Database, 2006). Still, some historical evidence of Lanna music indicates the types of instruments used at the time, including: kong (gong), klong (drums), salaw (a two-stringed fiddle), etc. In addition, historical documents showcase the role of music in the society for entertainment, warfare, or in ceremonial events (Na Nakorn, 1973; Vichiankeaw \& Wyatt, 2004). Today, Lanna music is categorised into two types, namely: traditional Lanna music and contemporary Lanna music. Artists may choose to play either type of the music or may choose to play both forms.

Traditional Lanna music consists of a number of instruments and ensembles. The $k \operatorname{long}(s)$ or drums, which are the traditional drums of local people, are influenced by the neighbouring cultures (Thammati, 2007). These drums are often used as drum ensemble to accompany traditional dancing in festivals, especially in the religious context (Dyck, 2010). The pat-kong ensemble, which is similar to the pi-phat ensemble, is seen in many regional cultures including central Thai, Lao and Cambodian, and contains musical instruments such as pat or ranad (wooden xylophone), kong wong (gong circle), nae noi (small oboe), as well as nae luang (large oboe), klong deng ting (a double-faced large drum). The important role of the pat-kong ensemble is that it is used in various festivals and blessings for auspicious and propitious ceremonies. The saw (singing) is a traditional performance consisting of singers called Chang Saw, who can be either male or female singing with pi joom (quartet of free-reed pipes) and sueng (a four-stringed lute) (Dyck, 2010). The singers sing the lyrics by memory and improvisation. The saw plays an extremely important role in the Lanna society in terms of being an amusement at festivals and other ceremonies (Wongskul, 2001). Currently, the singers try to use the easier and modern languages for audience's better understanding, and to improve the response to the performance (Chatipun, 1997). Moreover, saw is seen as a way to express and raise certain social issues (Kananai, 
2012). The Salaw-Saw-Seung ensemble is a new ensemble developed at the time of the local stream. This ensemble contains musical instruments such as salaw, sueng, klui (bamboo flute) and klong pong pong (a double faced drum). Formerly, these instruments were played only for personal entertainment. (Thammati, 2007, Songned, 2011). The salar-saw-seung is widely known in the Thai society because of its soft music style associated with the image of people in the northern society with the objective to support tourism in mass media and for advertising purposes. (Masiri, 2009)

Lanna contemporary music, however, is one that has been improved and developed from the traditional form. Traditional Lanna ensembles are played with Western music instruments, and a number of popular songs have been re-written and re-arranged for the purpose of this ensemble (Office of the Permanent Secretary, Ministry of Culture, 2018). The contemporary pat-gong is performed with a drum set, keyboard, electric guitar, electric bass, and some wind instruments. Thai popular songs and plang-lok-tung (Thai country music) are arranged to perform in festivals and spiritual dance ceremonies (Masiri, 2009). Likewise, the sor has been added and changed its rhythms in ways to make it more entertaining. In addition, some Lanna artists, such as Jaran Manophet, Panuthat Apichanathong, Bring-kop Warauri have adopted Lanna music including both songs and musical instruments to use in the form of a Western ensemble; a pop band or an orchestra (Sumrongthong, 2009)

Lanna music today has a relatively clear standpoint in social dimension. This unique style of music not only plays a role in entertainment and for rituals, it also plays a significant role in the identity of the society. It clearly contributes to the economy through the tourism business, and it certainly plays a part in improving the well-being of people in the society (Pitupumnak, 2017). In the dimension of professionalism, there are numerous traditional and contemporary Lanna musicians involved in the music scenes and performances.

From the past until now, the succession of Lanna music has held through a 'spiritual-teacher' belief system, which is the basic belief in transfer of knowledge and which was originated from the original Lanna people (Sumrongthong, 2009). In addition, the inheritance of Lanna music is related to the concept of community music education, which is a process of learning, absorbing and imitating, by creating musician's and teacher's identity (Pitupumnak, 2015).

Lanna music was previously inherited and maintained in the society by informal education and therefore, the existence of Lanna music in the community is becoming clearer when the Thai society has a local stream or localism (Pitupumnak. 2017). Localism has clearly existed in the policy of the Government since 1967 (Office of the national economic and social development board, 2016). This policy has an impact on the development of Lanna music in term of performing, music composition and arrangement, as well as in learning and teaching in the community, along with the academic study of this unique art. 


\section{Institutionalisation of traditional music (ITM) in Thailand}

The concept of institutionalisation of traditional music refers to the transformation and ways of teaching and learning traditional music from informal education to formal education. Many countries around the world have developed traditional music education in a form of conservatory, which is a type of Western music that is considered as formal education (Frank, 2014). Hill (2009) proposed that there are factors influencing ITM, namely: political and ideological agendas, nationalist agendas and leaders. The curriculum should therefore be dependent on the context of each culture and university. The ITM affects traditional music in many ways. Hill stated that "These programs can have huge impacts not only on musical transmission methods, but also on aesthetics, repertoire, style, performance practices, creative opportunities, hierarchies, political manipulation, economic considerations, valuation, status, and public perception" (p. 207-208). Meanwhile Frank (2014) argued that folk music curriculum had developed many aspects of local music such as creativity, academic knowledge, profession and identity development.

In term of the content and pedagogy in the curriculum, Frank (2014) suggests that learners must learn a variety of music, study theories and basics of notation, contemporary composition techniques and improvisation. For pedagogy, there are some controversies in ITM about the difference of pedagogy in conservatory and traditional forms. Frank stated that "the nature of traditional music itself allows for students to decipher it and make it their own" (p. 76). Students in the conservatory have to follow a score or composition, as well; they ought to determine the best way to perform. Therefore, the pedagogy is dependent on the character of music, instructors, as well as institution and department setting.

In the context of Thailand, ITM is evident when a change of government takes place, which results in political and educational actions. Traditional Central Thai music, or court music, was supported by government agencies and was used as a national music, titled classical Thai music, and was developed as a course in higher education by College of Dramatic Arts, Ministry of Culture (Thuntawech, 2017). This music has now been expanded to many universities around the country with the aim of preserving and transmitting national music. In the meantime, folk music, music in other regions, has been included in higher education in the form of elective courses (Sumrongthong, 2009). Some universities have developed folk music as a curriculum, especially in the north eastern part of Thailand.

In term of music curriculum development in a Thai context, some research has suggested that the music curriculum, both Western and traditional music, should be in line with the needs of learners, societies and economies, similar to the changing world of economics, and development of professionalism (Boonjae, 2014, Thuntawech, 2017). Moreover, there are laws and criteria that must be taken into account, namely the National Education Act and The Thai Qualifications Framework for Higher Education (TQF). The National Education Act emphasises that cultural inheritance is one of the means of education. It is the duty of the school to promote and integrate the cultural values with the teaching of all levels (Office of the education council, 2018), and to ensure that the TQF has set the curriculum 
standards in the field of Fine Arts. The content of the course should thus include: history, music, music theory, musical skills and music technology (Office of the higher education commission, 2016)

\section{Research Methodology}

The researcher used a phenomenological approach, which describes participants' interpretation of their lives experiences about a concept or a phenomenon (Creswell, 2017). The interpretation of experience is emphasised and presented as a theme and a sub-theme (Manen, 2003). The participants were selected following the theory of 'concept sampling', which examines individuals who can contribute to the evolution of a theory or concept (Creswell, 2007). 20 participants $(\mathrm{N}=20)$ from five institutions in Northern Thailand were selected including: 12 faculty instructors of Lanna music (code I1-I12), three administrators (code A1-A3), two independent scholars/experts (code S1, S2), and three (Lanna) musicians (code M1-M3). The researcher used various criteria for selecting each group of participants. The faculty instructors were chosen based on their academic standing or expertise, i.e. they had to be Lanna music instructors at the time of the research, had expertise in Lanna music, or had done prior research in respect to Lanna music. Furthermore, a number of faculty participants were also involved in developing curriculums. For the administrator's group, the researcher considered those who were heads of the music department. The independent scholars/experts were selected based on their area of interest in researching Lanna music and education. In addition, the researcher selected well-known musicians, who demonstrated continual musical work and performance, as well as recording and composition of music. During July-December 2017, formal interviews were conducted to collect data from each participant by questioning them about their experience regarding Lanna music in the society, in their profession, transition, education and institutionalisation. The researcher also utilised non-participant observation for collecting data about Lanna music, which appeared in the community and at the University. All data were managed by transcription, coding and analysis of specific statements and themes (Creswell, 2017).

\section{The Status of Lanna Music in Higher Education}

Lanna music is part of tradition, and tradition, as per governmental policies, constitutes an important part of higher education (Office of the education council, 2018). Findings suggest that Lanna music is manifested in higher education in the following forms: 


\section{Lanna Music as Cultural Identity}

Lanna music offers a cultural identity, demonstrating the receptivity of university personnel and dictates campus policies and activities. As highlighted in most universities' mission statements, the institution itself has to play a role in the preservation of arts and culture. The university has to offer, in terms of activities, succession and research on culture. Participant A1 stated that "Lanna music helps in fostering the cultural identity in our space. We are here. We have to make Lanna music reputable", Participant A2 indicated that "Our university serves the local community. We cannot neglect Lanna music."

Revivalist efforts began in Thai universities prior to 1993. Regionalisation in Northern Thailand is another factor in fostering the Lanna cultural identity. Musical clubs were established to offer opportunities for students to learn about or partake in Lanna music. Lanna music is employed in various occasions, such as in university activities or in institutional music. On top of this, Lanna music has also attracted the interest of university researchers.

Lanna music is also an attraction for artists and musicians, and a means of increasing the value of performance. This area of creative endeavour is often referred to as "Applied or Contemporary Lanna Music". This form of art is developed both within higher education and by independent musicians. It has been incorporated into many performances such as light and sound productions, telling the story of Chiang Mai's past and similar stories .

The development of music so far has an air of completion about it. Lanna music has become fused with Western music. I personally have done this for many years with nice tunes. Modern listeners enjoy it and some companies are interested in circulating it. (Participant I1)

In any case, from the university's point of view, Lanna music is more useful as a cultural identity than as a profession or academic pursuit. Focus is therefore often given to the restoration and preservation of Lanna music, generally through extra-curricular activities or as part of an existing curriculum.

\section{Lanna Music as Communal Activity}

From an academic perspective, Lanna music is often considered a folk tradition that is still serving the locals. Lanna music has its responsibilities to the community in several aspects, including the carrying out of religious rites (for instance, spiritual dances or funeral rites). Furthermore, Lanna music is also being fostered as a cultural identity, functioning as a tool for the development of youth and the elderly. These aspects have received much attention from university-based scholars in ethnomusicology and community music education. Studies show that learners are taught a Lanna tradition that is responsive to changing social contexts. There exist several bodies of knowledge integral to this system of education (in addition to musical skills), including music history, music and culture, as well as cultural transformations and changing demands for music, etc. (Pitupumnak, 2017). 


\section{Lanna Music As an Important Core of a Music Education Curriculum}

Although Lanna music has not yet become a specialised curriculum, it has been combined as part of music education curricula, which comprises of Western music, Central Thai music and folk music. The reasons for this grouping are twofold: 1) as an effort for preservation and 2) to equip students with a wide range of skills necessary to be able to teach different forms of music at school. Participant I8 stated that "The music education curriculum consists of Thai music because it is a national treasure; Western music because it is international treasure; and, Lanna music because it is a local treasure." Furthermore, Participant A1 stated that "The music education curriculum needs to create teachers with two areas of expertise: Thai and Western music. In Chiang Mai, folk music forms the third category."

Candidates in music education, therefore, need to be trained in a variety of musical traditions, in essence becoming music generalists since schools may not be able to afford specialists. A music teacher may have to oversee all kinds of schoollevel music depending on the school management. In some cases, the music teacher is also responsible for teaching visual arts and dance.

\section{Lanna Music as a General Subject}

Several universities offer courses in Lanna music, or in some cases Lanna music is admitted into the scope of pre-existing courses among Music Appreciation, Music and Rituals, or Ethnic Music (Akins, \& Binson, 2011). Lanna music is taught both to students of Thai or Western music, or to non-music students. These may be general education (GE) courses or free electives. In addition to this, subjects relating to society and local history may have a musical aspect to them; these may engage students in Lanna music without going too deeply into theoretical or historical details.

Thai music was usually the subject-matter of the Music Appreciation course nowadays, folk or Lanna music is also taught. Sometimes, history, which is a general subject, also includes Lanna topics, the ways of life of the Lanna people, including Lanna music, so that students may become acquainted with and better understand their own culture. (Participant I1)

Based on this wealth of information, it is evident that Lanna music is part of culture, the fostering of which should be one of higher education's main objectives. This mission is focused on conservation in all shapes and forms, including the development of cultural identity, research, along with the creation of bodies of knowledge for use in curricula or in individual subjects. These observations suggest that universities should place a great deal of significance on the instruction of Lanna music. In spite of this, Lanna music has not yet been developed as a specialised curriculum under the Ministry of Education, which is an important - yet untappedavenue for further growth in this area. 


\section{Paradigm for the Development of a Lanna Music Curriculum in Higher Education}

This paradigm towards a specialised Lanna music curriculum offers a roadmap for further development in response to social needs and context. The following are findings based on interviews, and analysed below under the succeeding headings:

\section{Objectives of the Curriculum}

The participants provided information regarding the objectives that relate to their experience. The key concept of the data is preservation and creativity. The participants stated that:

In the creation of a curriculum, emphasis must be placed on preservation, in tandem with the application of Lanna music to newer contexts. (Participant A1)

The integration of traditional and Western music must be emphasised. The participant I3 pointed that:

Considerations must be given to the integration between Lanna and Western music. In some cases, curricula place an over-emphasis on Western music at the expense of local music. Methods of learning may include rearranging of folk music for modern usage, or utilising traditional instruments. (Participant I3)

From the viewpoint of the ability, graduates become prospective music teachers or musicians of good quality and are able to use materials of Lanna music as a foundation for their own creative work in terms of teaching innovation and music creativity.

In order to study the music, one must have the capacity to combine the original with the new. Then, connect and adjust them as they best suit our society and culture. (Participant I4)

One participant state that "the thinking process is an important outcome for developing any creative work".

I think we should focus on the "idea" of thought because we lack the thinking process. We like imitation. If I am asked, it must be rebuilt. For example, we may not take music across species. We might create a Lanna Symphony which is a Salo, Sor, Sueng in Symphony. (Participant I5)

The graduates are expected to have the ability to develop their own ideas after graduation. The participant I6 said that:

I think the graduates will have their own ideas, creativity in self-development and finally, they can create their own work which will be a successful point." (Participant I6) 
In addition, the traditional way of Lanna music should be included in the curriculum as a basis for creativity.

The practical teaching, such as the teaching of "Bhu Cha drums, Phu Jae and Sa Bad Chai, are all aimed to teach the students to understand and to apply these into their works. (Participant I3)

The main objective of a Lanna music curriculum should therefore be 1) to restore bodies of knowledge that help in preserving and acting as the way for the transference of Lanna music, 2) to foster Lanna music creativity based on traditional music and music of other cultures, and 3) to ultimately lead to professionalism (musician and music teacher) in modern-day society. This concept is in line with the demands of higher education in its objective to preserve local traditions, as well as to respond to the demands of society and the learners themselves.

\section{Availability of Resources}

In the northern regions of Thailand, there is a wealth of cultural resources due to diversity of peoples and cultures, folksongs, artists and teachers, independent musicians and other musical events. Much has been documented in photographs, videos, sound clips and other sources, which lend themselves to classification and scholarly investigation. The participants stated that:

Different materials can be found within our area. We have ethnic diversity. We have different types of play. All these things can be incorporated into a creative work to create a new kind of performance. Different musical identities can be found throughout the northern provinces. (Participant I8)

From a viewpoint of a musician, participants should include a variety of cultural materials in their creative work. The participant M2 said that:

We have ethnicity. We have a variety of traditional games. We have a set of fabrics that can be used for further creative thinking in order to make a new show. It looks like it is our selling point. (Participant M2)

On the other hand, the body of knowledge of Lanna music inherited from a 'master' or 'Khru' is an important resource, and should be further developed. The participant A3 proposed that:

We have a lot of knowledge and wisdom. Also, there are a number of experts called Pho Khru and Mae Khru. But, their knowledge have not yet been fully utilized and transferred into practical textbooks. In order to create a curriculum, we have to initiate these. (Participant A3)

In respect to instructor's competencies, Thai laws require instructors in higher education to have several qualifications, such as possessing a related degree in at least a master's level, as well as having conducted research or produced academic publications (Office of the higher education commission, 2015). Nevertheless, in reality, those who have accurate knowledge of folk music and a 
high level of education are almost non-existent. It is, therefore necessary to develop certain criteria in order to identify the actual abilities of instructors and local artists, who are capable of providing higher education. Some universities in Thailand have the criteria to support those who are highly talented yet lack the knowledge. This includes national artists or those who have received national awards. Participant A3 pointed out that:

You need to set specific criteria to support good artists, who can teach in the university. They may need to have recognized achievements, and there should be a committee or board to review their background, as those who have a Ph.D. in Lanna music are not existent. (Participant A3)

In the process of developing a Lanna music program, the university must invest in such facilities like music rooms, musical instruments, computer programs, recording rooms and showrooms. These facilities need to be available and wellequipped in order to best serve learners and have maximum impact in terms of learning outcomes. However, some participants revealed that:

Folk music has to stay and continue with villagers. We have to place emphasis on teaching-learning and performance in the community. Considering the fact that musical instruments are often made by the villagers themselves, musicians (students) may have to create their own musical instruments. (Participant S1)

One of the participants stated that the program should begin from what's available, and gradually be expanded from that point on.

What we have for the support is gradual accumulation. We started by learning from what we had before, and have gradually created both knowledge and things. (Participant I9)

However, the quality of the curriculum needs to be considered. The participant A2 said that:

We cannot expect to have all facilities ready and then start designing a curriculum. We ought to ensure that we create high quality curriculums, while the facilities are being developed. (Participant A2)

The participants stated that they could use the facilities that had already available, and what they needed in terms of high investment, they could accumulate or gradually build up. Participant A2 stated that "But, we must critically think about the quality of teaching and the quality of our students."

For the development of a Lanna music program, the participants stated that the readiness of resources should be taken into account. This includes providing information regarding the availability of resources, including knowledge, personnel and facilities. These are elements that are related to the community and the original space of teaching-learning of Lanna music. In addition, the knowledge of Lanna music, in its entirety, appears in various aspects of music theories, music history, 
practical techniques and the music culture. It is in the practice of wisdom and succession with oral tradition. However, the academic knowledge developed in the character of textbooks is limited and not comprehensive. Therefore, the university needs to support research and development of knowledge in various fields as a basis for curriculum development.

\section{Development of Learners Based on Interest and Potential}

Lanna musicians are diverse. Before enrolling in higher education, students learn Lanna music in various ways based on their musical interests and through their preferred learning styles. The learners may learn from their parents, masters, friends, or by themselves and via resources available on the Internet including YouTube. Some musicians may play only one type of Lanna music, while others may be interested in playing multiple types of music, including the ability to perform traditional Lanna dance. This diversity affects the qualification of the students that need to be broadly defined.

As we have observed over the years and as it is evident from existing courses, our students are very different. Many of them, who are capable of playing Lanna music, come from different places. We try to get them to use that ability. If we will do the Lanna music course, a broad set of criteria must be set and it cannot be specific. (Participant A1)

The difference between students directly impacts their recruitment criteria. The participant A2 stated that:

The criteria for student recruitment must be diverse and flexible. We need to see that students have the potential to further develop in their own way. (Participant A2)

Consideration must also be given to the development of learners based on differences in their interests and potentials. One method of folk performance involves artists being able to develop musical forms by themselves, both in traditional and contemporary styles. The learner must therefore be able to develop his own expertise, as well as learning about other different types of music in order to achieve creative autonomy. Participant I5 stated that "students must create their own work according to their own potential."

In order to develop the potential of learners, besides creating courses and curriculum content, the participants agreed that teachers have a great impact to support and encourage students to develop their full potential.

Every student has different needs and goals. Some like folk music and come to study folk music from local experts. Students come to study with us, which opens their world and encourages them to further learning. (Participant A1) 
In addition, it is the teacher's duty to lead students and to help them develop their potentials. The participant I7 stated that:

Teachers do need to help and point out what students can do. Previously, with Thai music and Western music we try to do that. (Participant I7)

From a different perspective, universities are a place of learning and intellectual exchange between learners. The duty of the teacher is to find inspiration and to offer advice. The curriculum should therefore foster a diverse learning experience, so that learners may receive the knowledge needed to accompany their own creative pursuits.

\section{The Provision of Diverse Knowledge, Leading to Professional Qualification}

The music industry in Northern Thailand, including the Thai society, is divided into two major groups: musical profession (musicians, music composers, producers); and music teachers (teaching in public schools, private schools and private studios). Each line of work can be subdivided into very specific categories. In this case, Participant I11 informed that:

We do not know what graduates will choose after their graduation. Some people learn to become an artist, while others study liberal arts and finally pursue a teaching job. These are based on the opportunity they encounter. (Participant I11)

Graduates will soon face diversity and expectations. Graduates, who become music educators, are required to have a diverse understanding of different forms of music. Although, in higher education, students will have their own major areas of expertise, they may be encouraged to learn instruments with which they are unfamiliar, or even learn subjects for which they have not been adequately prepared, for instance physical training or drawing. At the same time, school standards differ from place to place in funding, in the quality of the staff, location, social influence and so forth. In face of this great diversity, graduates must adapt and be able to handle a wide range of unexpected situations.

A graduate from a Lanna music curriculum must respond to the needs of different local schools. In addition to Lanna music, he may have to be trained in Thai music. Upon graduation he may land a job in a faraway school, or one lacking adequate budget. He will have to demonstrate abilities in Thai music, Western music and folk music. (Participant S2)

The desire of most schools is to establish school bands capable of attending various school activities, representing the school in contests and putting the school's name in good repute. A number of schools therefore are in need of regular teachers capable of organizing bands. The curriculum should respond to this demand by producing candidates able to conduct bands of both folk, Thai and Western music. 
Participant I10 stated that "In some situations, schools expect music graduates to be able to form bands, whether it is for western, Thai or folk music."

In the music profession, diversity of knowledge leads to more creativity and innovation, which should be one of the main objectives of the adaptable music curriculum. The design of the curriculum, in addition to requiring students to develop expertise in their own disciplines, must also train them to think in more cosmopolitan terms, leading to more diverse opportunities within the profession. The participant said that - in case of Thai music students:

Thai music students only learn about Thai music. So when they encounter Lanna music or other musical traditions, they come to a dead end. Even in terms of the notation - they're only often taught the notation of Thai music, and none of the Western. They come to a dead end. (Participant I11)

Reading western notations is a necessary skill for communication between traditional and western musicians. The participant A1 stated that:

When they encounter Lanna or Western musicians, they have problems communicating with them. Learning about other musical traditions or foreign notation may be a necessity.(Participant A1)

In addition, students also need to know various styles of music, which help them to satisfy customers' different needs. The participant M1 said that:

I work as a freelance, composing a number of songs. The key I found is to determine different needs of customers. Even when we have our own ways, we have to consider what customers want or what we should offer our customers. We need to know a lot. Knowing just native music or Western music is not enough. (Participant M1)

The curriculum therefore needs to prepare the graduates to face the diversity and expectations. Students should have a grasp of different traditions of music, whether it is Lanna, Western or the music of other cultures. This process of learning should tie in with concepts of ethnic music, as well as that of music education and creativity, so that the students may achieve a more wholesome integration in their works.

\section{Freedom to Develop a Local Curriculum}

The design of a Lanna music curriculum, which is mainly concerned with a local body of knowledge, should be given enough freedom and flexibility to engage with the local context. Even if curricula must be written with social, economic, cultural and political considerations in mind, in Thailand, curricula must conform to governmental policies, known as Thai Qualifications Framework for Higher Education. Every curriculum must rigorously follow these guidelines. On top of this, additional rules set by the Teachers' Council apply to the development of postgraduate curricula. 
The criteria laid down by the Teachers' Council present a lot of difficulties. The university should have some flexibility and freedom in curricular decisionmaking, so that they may decide on what's best based on local contexts. Regional curricula will be different due to social, environmental and cultural differences. (Participant I12)

Such criteria may be rigorous in certain areas, such as in regulating the qualifications of the teaching faculty and the distribution of credits and modules, to name a few examples. However, a context-aware curriculum can still be designed based upon relevant bodies of knowledge to ensure the design of courses and course contents are in alignment with the vision of the university. In any case, this must measure up against the standards of the profession and the field of study.

\section{Significance Given to Cultural Diversity}

For curriculum development, it is important to consider the diversity of students together with institutions that play a significant role in developing academic knowledge, as well as the need to focus on the diversity of Lanna music culture. As mentioned earlier, the word 'Lanna' encapsulates traditions within the Northern Thai regions. In this way, Lanna is by definition a diverse conglomeration of traditions based on fluctuating population. Moreover, this may also include the surrounding music cultures that influence Lanna music, such as Burmese music culture, Tai, Laos, etc. A Lanna music curriculum should therefore reflect this essential diversity rather than confining itself to a singular mainstream musical tradition. The participants said that:

A Lanna music curriculum should not place, at its heart, a singular emphasis on Lanna music, but rather attend to ethnic diversity. (Participant I8)

What is the real Lanna music? What kinds of Lanna music should be included in? The Lanna music program is not going to be only concerned with salaw, saw, sueng, and pat-kong. (Participant S1)

Lanna music is therefore not just the music of Chiang Mai, the central hub of the region, but also the music of other cultural minorities, such as music from the hilltribes, or music in each province in Northern Thailand. Each province has its own history of royal courts such as Nan, Payao, Chiang Rai. The Mae Hong Son province however, derives much of its influence from the Shan peoples of Myanmar. Moreover, each province has its own way of playing music, which deserves its unique research endeavour and learning. This local history and the way of playing are important parts of developing a Lanna music curriculum. In addition, the program should also include Western music that has played a role in Lanna music, specifically Lanna contemporary music. In consequence, the development of the Lanna music program requires the use of branch concepts and Ethnomusicology in order to define the subject and direction. As participant A3 stated: 
To make students understand the diversity, it is crucial to get them involved with a background culture and to provide them a view on the musical culture; it is a subject that is Ethnomusicology. (Participant A3)

In terms of cultural diversity, both music and other related cultural elements are the hallmarks of Lanna music as well as folk music, similar to many cultures around the world. The curriculum needs to take into account the direction of curriculum development.

\section{A Curriculum for the Community}

As it was pointed out under the topic of "Availability of Resources", the participants emphasized that the Lanna music program cannot be separated from the community, even if it is taught in the university. Lanna music has its roots in communal tradition. Beyond the university, the community is a place for creativity and transmission, with an active and continuously developing musical scene (i.e. developing new musical forms, new styles of performance, etc.)

Lanna music courses must work with communities because knowledge and meaning of Lanna music are in the community. Music is born with people and is developed with the artists and the audience. These people are in the community. (Participant S3)

The community is therefore an ideal place for learning about Lanna music. The curriculum must therefore seek to develop its vision, its faculty, contents and learning activities to reflect this social reality. Courses might include Music in Modern Day Rituals, Music Aesthetics and Society, Community Music, Community Music Education, the Management of Professional Lanna Ensembles and so forth. Additionally, credits could be awarded to students for experience working in the community as a way of encouraging mutual work between the university and the community. The participants said that:

In order to design the subjects, institutions must consider what kinds of essential knowledge students need to learn. Consider the need and the changes that will occur. (Participant I4)

The critical point is that how it will also connect with the community in terms of both the knowledge and teaching, or even the credits transferred. (Participant S3)

Conversely, the university is an academic space for Lanna music, attending to the preservation and improvement of important bodies of knowledge - knowledge currently in the possession of an ageing generation of teachers and artists. Participant A1 said that "There are problems within the present method of cultural transmission. The teachers are getting older, but education can preserve this wealth of knowledge."

All this knowledge demands to be preserved and studied in a systematic way. Many universities see value in this work and have tried to collect these bodies of knowledge in the form of research that is managed by the faculty or researchers. 
In any case, research must continue to be promoted, expanded and in turn be fed back into the curriculum-building process.

\section{Conclusion}

This article reviews the status of Lanna music in modern educational institutions and offers a paradigm for the development of a Lanna musical curriculum. The results suggest that, presently, Lanna music in higher education plays a role in shaping the cultural identity of the region. Lanna music is a communal activity and a field of study for many researchers in universities. Lanna music is also a central aspect of a music education curriculum, in which students must take courses in Western, Central Thai and folk music. Additionally, Lanna music is a general subject taught to non-music students, or a subject incorporated into other existing courses. The development of a Lanna music curriculum should adhere to the following paradigm. The goal of the curriculum should be to preserve and develop existing musical traditions. Considerations must be given to the availability of resources, in particular, the cultural resources which form vital foundations for the creation of bodies of knowledge. Students should be developed based on their interests and existing potentials. Certain flexibility and freedom must be afforded to the development of a local curriculum, which responds to local contexts and demands, reflecting national standards and criteria. The curriculum should take into consideration cultural diversity and the possibility of integration with the community. Furthermore, from the demand and the perspective presented above, it is evident that the development of a Lanna music program must include the concept of music education and ethnomusicology, music performance and creativity in order to provide students with a broader understanding of various cultures, conveyances and musical creations.

This research will be the principle platform for developing Lanna music curriculum in higher education, especially in the northern region of Thailand. This research intends to create a starting point for developing ideas and paradigms that are necessary to support other studies which may lead to the successful development of the curriculum in a systematic manner, and which is in line with the changing societies of the $21^{\text {st }}$ century. Future studies should be developed to include details on the components of the curriculum, especially Lanna music theory, Lanna music history, Lanna musical practice and Lanna music pedagogy. These are important factors for teaching and learning. Higher education and community would help support each other's content, learning and teaching, as well as the measurement and evaluation, including transferring credit from community teaching and learning to formal education. 


\section{Acknowledgements}

The contents of this article derive from a research entitled 'The Paradigm of the music study in Higher Education in Northern Thailand for $21^{\text {st }}$ Century', sponsored by the Thailand Research Fund (TRF) and received great support from Chiang Mai University, the Faculty of Fine Arts, and all contributing informants.

\section{Reference}

Akins, J., \& Binson, B. (2011). Transmission of traditional lanna music in Chiang Mai: Continuity and change in a contemporary urban environment. City, Culture and Society, 2(4), 243-254. DOI:10.1016/j.ccs.2011.08.00

Boonjae, A. (2014). Krabunkan plianplaeng lae naewnom khong kanson dontri nai sathaban udomsueksa : koranisueksa mahawittayalai rajabhat Bansomdegchaopraya[Change process and new trends of music teaching: a case study of Bansomdegchaopraya rajabhat university]. (Unpublished Doctoral Dissertation). Mahidol University, Nakornpathom, Thailand.

Chatipun, C. (1997). Kan rap khawsan dan chariyatham chak sue puenban praped sor khong prachachon nai ampher San Kam pang, changwat Chiang Mai [The reception of moral information from a tradition folk, in Sankampang: A case of "saw"] (Unpublished master's Thesis). Chulalongkorn University, Bangkok, Thailand.

Creswell, J. W. (2007). Education research: Planning, conducting and evaluating quantitative and qualitative research. Upper Saddle River, NJ.: Pearson Education.

Creswell, J. W. (2017). Qualitative inquiry and research design: Choosing among five approaches (4th ed.). USA.: SAGE

Dyck, G. P. (2010). Musical journeys in Northern Thailand. Massachusetts, MA: Minuteman Press of Fall River.

Frank, A. (2014). That's the way I've always learned: The transmission of traditional music in higher education (Electronic Theses and Dissertations, Paper 2381). Retrieved form http://dc.etsu.edu/etd/2381

Hill, J. (2009). The influence of conservatory folk music programmes: The Sibelius Academy in Comparative Context. Ethnomusicology Forum, 18 (2), 207241, DOI: 10.1080/17411910903141882

Kananai, P. (2012). Kan prappian botbat lea nati phue kan damrongyu khon "saw" thamkhlang boribot khong sangkhom ti plianplaeng : koranisueksa khanaso amphoe Maerim changwat Chiang Mai [Role Changing and Existence of "Saw" Among Dynamic Social Context: A Case Study of "Saw" Bands in Mae Rim District, Chiang Mai Province]. Phikante Journal, 8(1), 25-32

Kanteewong, T. (n.d.). The re-contexualisation of Lanna traditional music in Chiang Mai province, Thailand. Retrieved from http://www.cujucr.com/downloads/pdf_7_2009/Thitipol\%20Kanteewong.pd $\mathrm{f}$ 
Manen, M. V. (2003). Researching lived experience (2nd ed.). London, Ontario: Althouse Press.

Masiri, P. (2009). Pat kong: Wong pi-pat nai boribot sangkhom Chiang Mai patchuban [Patt Gong : Pi Phat Lanna in present context of the Chiang Mai society] (Unpublished Master's thesis). Mae Fah Luang University, Chiang rai, Thailand.

Na Nakorn, P. (1973). Khlong Nirat Haribhunjaya [Nirat Haribhunjaya poem]. Bangkok: Prachan.

Office of the education council. (2018). Phraratchabanyat kansueksa 2542

[National Education Act B.E. 2542]. Retrieved from

http://www.onec.go.th/index.php/book/BookView/10

Office of the higher education commission. (2015). Kenmattatan laksut radap parinyati 2558 [the criteria of the undergraduate curriculum B.E. 2558]. Retrieved from

http://www.mua.go.th/users/hecommission/doc/law/ohec\%20law/2558\%20 gradu\%202558.PDF

Office of the higher education commission. (2016). Mattatan khunnawut radup parinyati sakha silapa kamsat 2558 [Thai qualifications framework for higher education in Fine arts B.C. 2558]. Retrieved from http://www.mua.go.th/users/tqf-hed/news/news6.php

Office of the national economic and social development board. (2016). Phaen phattana saetthakit haengchat chabapti 2 (2510-2514) [The 2nd national economic and social development plan (1967-1971). Retrieved from http://www.nesdb.go.th/main.php?filename=develop_issue

Office of the Permanent Secretary, Ministry of Culture. (2018). Sueng chord:

Nawattakam dontri Lanna nai sattawatmai [Sueng Chord: the invention of Lanna music instrument in the new century] (research report). Chiang Mai: Author.

Pitupumnak, K. (2014). Dontri Lanna: Kan wichai domtri chatphanwitthaya nai radab bandit suesa [Lanna music: Ethnomusicological research in graduate study level]. Plang Dontri, 20 (4), pp 28-35.

Pitupumnak, K. (2015). Attalak kru dontri puenmueng nuea koranisueksa phokru Manop Yarana, phokru Un-ruean Hongtong lea kru Bunying kanthawong [Northern Thai Traditional Music Teachers's Identities : The study case of Manop Yarana, Un-ruean Hongtong, and Bunyinng. Kanthawong]. Journal of Fine Arts, 6 (2), 138-169

Pitupumnak, K. (2017). Nueaha lea krabunkanrian-kanson nai rabop dontri chumchonsueksa nai puenti changwat Chiang Mai [Content and TeachingLearning process in community music education in Chiang Mai province, Thailand]. Journal of Fine Arts, 8 (2), 265-320

Songned, K. (2011). Kan suepthot salo nai wattanatham Lanna [The inheritance of sa-law in Lanna music culture] (Unpublished Doctoral Dissertation). Mahidol University, Nakornpathom, Thailand.

Sumrongthong, B. (2009). Phitikam lea kwamchue ti kiawkhong kap wattanatam kan seup thot dontri Lanna [the Rites and Beliefs associated with the 
transmission of musical culture in Thailand's Lanna Region] (research report). Bangkok: The Thailand Research fund.

Thammati, S. (2007). Natta duriyakan Lanna [Lanna Dance and Music]. Chiang Mai: The Center for the Promotion of Arts and Culture CMU.

The inscriptions in Thailand Database. (2006). Charuak wat pra yuan [the inscriptions at Pra Yuan temple]. Retrieved from

http://www.sac.or.th/databases/ inscriptions inscribe_detail.php?id=188

Thongkam, C. (2014). Dontri phuenban kap kan pen laengrianru khong changwat

Nan [Local music and being learning resource of Nan province]. Area

Based Development Research Journal, 6(4), 65-109.

Thuntawech, S. (2017). The ideal Thailand music institute in higher education in the

21 st century (Unpublished Doctoral Dissertation). Mahidol University, Nakornpathom, Thailand.

Vichiankeaw, A. \& Wyatt, D. K. (2004). Tamnan Pueng Muang Chiang Mai [The

Chiang Mai chronicle] (2nd ed.). Chiang Mai: Silkwormbooks.

Wongskul, S. (2001). Kan khong yu khong phleng phuenban (sor) nai changwat

Chiang Mai [Retention of Traditional Lanna folk song (Sor) in Chiang Mai

Province] (Unpublished master's Thesis). Chiang Mai University, Chiang

Mai, Thailand.

\section{Biography}

Khanithep Pitupumnak is currently a lecturer at the Department of Thai Arts, Faculty of Fine Arts, Chiang Mai University, Thailand. Pitupumnak is interested in fields of Ethnomusicology, Community Music Education, and Multi-Cultural Music Education. 